\title{
Initial Training of Primary School Teachers: Development of Competencies for Inclusion and Attention to Diversity
}

\author{
Carmen Nuria Arvelo-Rosales *, Olga María Alegre de la Rosa (D) and Remedios Guzmán-Rosquete \\ Department of Didactics and Educational Research, Faculty of Education, Universidad de La Laguna, \\ 38200 San Cristóbal de La Laguna, Spain; oalegre@ull.edu.es (O.M.A.d.1.R.); rguzman@ull.edu.es (R.G.-R.) \\ * Correspondence: cnarvelo@ull.edu.es
}

Citation: Arvelo-Rosales, C.N.;

Alegre de la Rosa, O.M.;

Guzmán-Rosquete, R. Initial Training of Primary School Teachers: Development of Competencies for Inclusion and Attention to Diversity. Educ. Sci. 2021, 11, 413. https:// doi.org/10.3390/educsci11080413

Academic Editor: Eila Jeronen

Received: 2 July 2021

Accepted: 29 July 2021

Published: 9 August 2021

Publisher's Note: MDPI stays neutral with regard to jurisdictional claims in published maps and institutional affiliations.

\begin{abstract}
Teachers need to be prepared to attend to all learners regardless of their abilities or needs. This implies that future teachers must develop, throughout their initial training, the necessary competencies to provide inclusive education to all students. The aim of this research was to analyze the level of development of competencies related to inclusion and attention to diversity among university students of a degree in primary education. Based on the project developed by the European Agency for Development in Special Needs Education (EADSNE) on the profile of the inclusive teacher, an ad hoc survey was prepared based on the four fundamental competencies proposed: valuing student diversity, supporting all students, working as part of a team, and developing one's professional and personal qualities. This survey was administered to 440 students of the degree in primary education from the University of La Laguna (San Cristóbal de La Laguna, Spain). The results showed a positive development of the four competencies, with a higher development of the competencies of continuing professional development. It was also found that the students had the knowledge, skills, and attitudes necessary for promoting inclusion and encouraging attention to diversity in their classrooms.
\end{abstract}

Keywords: inclusion; primary teachers; diversity; competencies

\section{Introduction}

Diversity can be found in all areas of life, including education. This implies the need for developing an inclusive school that guarantees equal opportunities, student participation, cooperation, and attention to diversity as well as one that offers quality education [1]. Therefore, it is necessary that primary education teachers be prepared for and develop the necessary competencies to attend to diversity and offer a quality, inclusive school. With this perspective, the question that guided our research was: what is the level of development of competencies related to inclusion and attention to diversity among university students with a current degree in primary education?

Inclusion encompasses more than educational attention to students with difficulties. An inclusive school must have the capacity to attend to all students and offer a teachinglearning process appropriate to their needs or abilities. In the words of Diaz [2], the inclusive school must be an institution capable of:

Accepting the complexity and diversity of people who are immersed in the education system, in the sense of reformulating the paradigms of education in favor of the equal inclusion of those who will be participants in society, not only of those with special educational needs, but of everyone who requires training and to start a teaching-learning process in an educational establishment. The notion linked to this concept is that each individual is unique, that he or she has grown up and developed in a particular context and that he or she possesses characteristics inherent to his or her family environment [2].

From this perspective, we speak of the diversity of the student in terms of learning. Therefore, the educational process is not aimed at a homogeneous group, but is aimed at each student based on their diversity and considering their learning style and pace [3]. 
In this sense, the creation of an "effective education for all is proposed, based on the idea that schools, as educational communities, must meet the needs of all students, whatever their personal, psychological or social characteristics (regardless of whether or not they have a disability)" [4] (p. 17). The aim is, therefore, a comprehensive, flexible, creative school, etc., capable of educating the entire population [5], as it is considered that students' learning success "is maximized when they are provided with experiences that build on their initial competence and respond to their learning needs" [2] (p. 71).

Hence, inclusive education entails strengthening the education system such that it is able to reach all people, as education is understood as a fundamental and basic right for the development of a fair and more equal society. [6] In this sense, UNESCO [6] provides the following definition:

"Inclusion is thus seen as a process that enables due account to be taken of the diversity of needs of all children, youth and adults through increased participation in learning, cultural and community activities, as well as reducing exclusion from and within the sphere of education, and ultimately ending exclusion" (p. 9).

Inclusive education, therefore, refers to the recognition of students' uniqueness, the valuing of their potential, and their participation in the life of the school, taking into account their abilities [7]. One of the great challenges for education today is to offer students a teaching-learning system in accordance with their needs, motivations, learning style, etc. $[1,8]$. In this context, teacher training is essential for addressing this diversity and promoting inclusion, as it is the teachers who must develop strategies to meet the needs of their students $[9,10]$ and who therefore must plan, implement, and evaluate educational practices that are accessible to all [11].

Furthermore, changes in European policies have led to the creation of the European Higher Education Area (EHEA) and subsequently to the creation of new university degrees. This new perspective requires the acquisition and development of competencies that guarantee that students will be able to develop effectively throughout their lives [12-14]. In order for educational practices based on the inclusion of all students to be successful, the initial training of future teachers becomes a key element, providing them with tools and strategies to offer a quality educational response to all students, regardless of their specific characteristics or qualities [15].

Idol [16] demonstrates several indicators of success within inclusive practices, such as the attitude of the members of the educational community, the perception of their abilities to modify the curriculum and manage the classroom, the types of difficulties their students have, the amount of support staff they can depend on, etc. This highlights that teachers are a key element in everything, as their attitudes, perceptions, beliefs, and feelings about inclusion will influence the way they act and care for all learners [15]. Teachers' attitudes influence students' self-esteem, motivation, and learning, and may affect them positively or negatively $[17,18]$.

Therefore, teacher training should be seen as a fundamental element for achieving inclusion. The initial and continuous training that teachers receive will provide them with the tools and strategies to offer a quality educational response to all students, regardless of their specific characteristics or qualities [15]. Teachers are responsible for responding to diversity and developing appropriate methods to meet the needs of students $[9,10,19]$. In addition, the lack of initial or continuous training may lead to disinterest in and rejection of students with difficulties $[17,18]$.

Along these lines, Alegre and Villar [20] reflect on the importance of teachers' abilities and on how they influence a teacher's work with students. They consider that an inclusive teacher must have both content knowledge and pedagogical knowledge, as well as be able to manage student behavior in the classroom and work in collaboration with families and other professionals. This makes it crucial that throughout their training they develop competencies (i.e., knowledge, skills, and attitudes) that enable them to be inclusive teachers and develop skills that will help them to take responsibility for all learners and manage their learning [21]. 
There are several studies focused on analyzing the knowledge, skills, and attitudes toward diversity by teachers, as well as their training needs and their beliefs regarding inclusion. Amr et al. [22] specified that one of the factors that most influences the attitudes of teachers is their level of knowledge about addressing diversity and using different teaching and evaluation strategies to respond to the needs of students in the classroom. Bawa et al. [23] analyzed teachers' attitudes toward inclusion and their relationship with perceived self-efficacy in their educational practice. Pegalajar and Colmenero [24] analyzed attitudes and needs for teacher training in terms of inclusion. Gonzalez-Gil et al. [25] conducted research to assess the perceived training needs for promoting the inclusion of school teachers, while Avramidis et al. [26] analyzed the attitudes of teaching students about inclusion.

Following this line of thinking, the Teacher Education for Inclusion (TE4I) project was developed. This program sought to answer the question "how can we prepare teachers in their initial teacher training to be inclusive?" [21] (p. 7).

This report shows that interpersonal and collaborative competencies are essential for working with other professionals and with the family in order to respond appropriately to educational needs. In addition, there is a need for lifelong learning and initial training that addresses the development of attitudes and values that are fundamental to inclusion. Institutions that train teachers and professors need to collaborate to ensure the implementation of appropriate educational models-models that include interaction with people with needs, as this is a fundamental element for the improvement of training quality at both the theoretical and practical level [21]. From this project, a teacher profile for inclusive education was derived based on four competencies: valuing student diversity; supporting all students; working as part of a team; and developing one's own professional and personal qualities. These competencies are then divided into different competency areas, as can be seen in Figure 1.

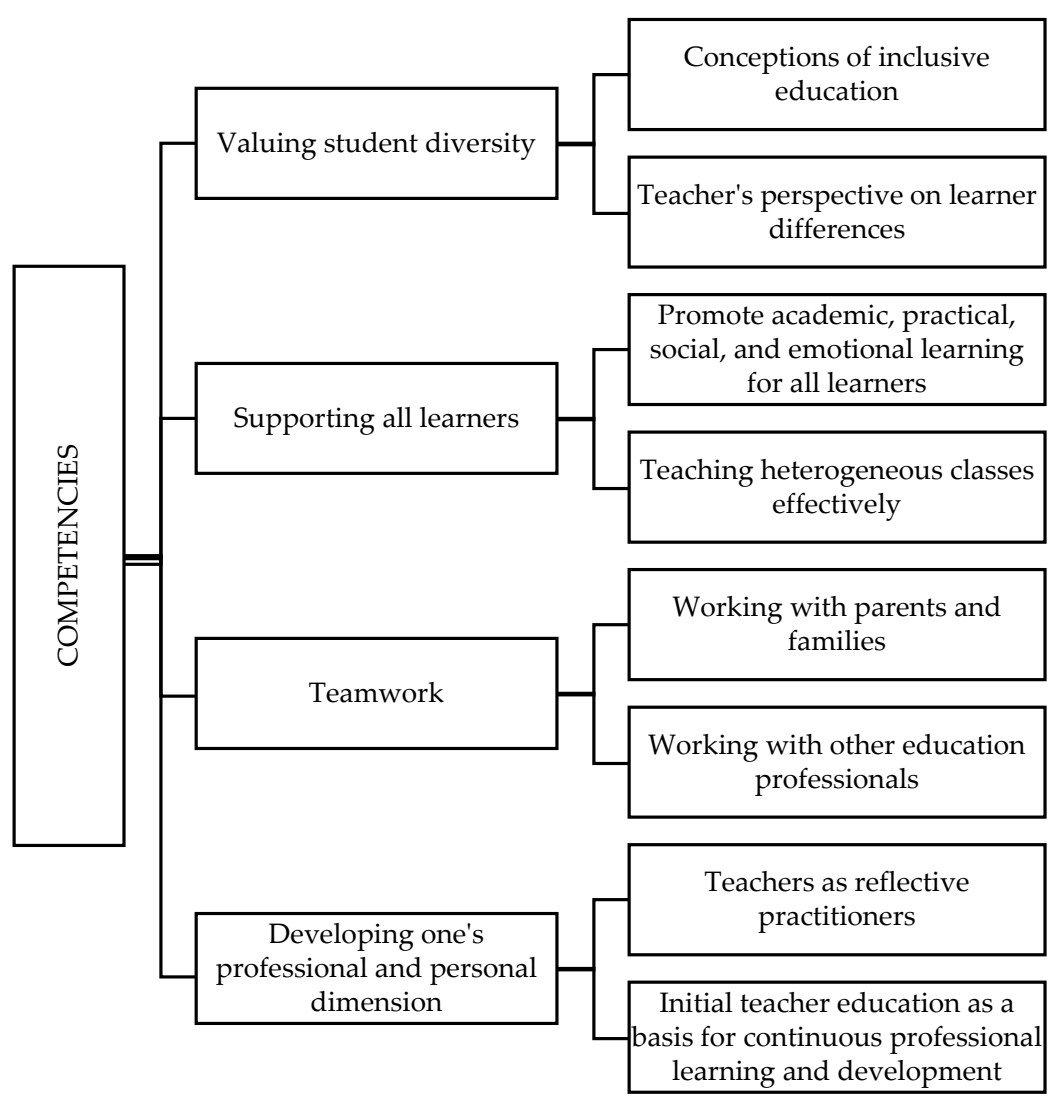

Figure 1. Teacher profile for inclusive education (own elaboration based on EADSNE [21]). 
These four competencies comprise attitudes, beliefs, concepts, theoretical and practical principles, skills, and essential capacities [27], which are listed below:

- Competence: valuing the diversity of learners: education is based on a belief in equality, human rights, and democracy for all learners. Meaningful participation of all learners in activities is necessary; it is not enough that they have access to education. It is crucial to identify the most appropriate ways to respond to diversity and to know the terminology and language of inclusion and diversity. Teachers should perform self-assessments of their own beliefs and attitudes and how they influence engagement with the diversity of learners.

- Competence: supporting the whole student: this involves promoting the academic, practical, social, and emotional learning of all students and knowing that teachers' expectations influence student success. Knowledge of learning models and supports for the learning process is necessary, as well as using alternative teaching methods, flexible teaching and providing feedback to learners. It also includes valuing collaborative work with families and communicating appropriately, both verbally and non-verbally, to respond to the needs of learners, families, and other professionals.

- Competence: teamwork: this refers to valuing the effective participation of parents and families to support students' learning and recognizing the benefits of working collaboratively with other education professionals and participating in school evaluation and development processes. It implies an approach to teaching that includes working with pupils, parents, other schoolteachers, and support staff as a multi-disciplinary team.

- Competence: developing one's professional and personal dimension: initial teacher education is the basis for continuous professional learning and development. Teachers must be reflective professionals because teaching is a conflict-resolution activity that requires systematic planning, review, and modification. They need to know methods and strategies for evaluating their own work and performance, as well as being aware of current legislation and regulations and their responsibilities toward students, families, and other professionals.

These competencies are not only for teaching or responding to students with educational needs; to the contrary, they also provide teachers with competencies to work with all of their students. The aim of this study was to analyze the level of development of competencies related to inclusion and attention to diversity among university students of the degree in primary education.

\section{Materials and Methods}

A non-experimental, cross-sectional, and descriptive design was followed with the aim of measuring the development of competencies for educational inclusion, through a single data collection at a specific time [28-30]. The following research questions were used:

- Q1: Do university students of the degree in primary education at ULL have the competencies related to inclusion and attention to diversity?

- Q2: Are there differences in the development of competencies on inclusion depending on gender, the year in which they are enrolled, or contact with a person with educational needs?

- Q3: Have the students of this degree developed the knowledge necessary to deal with diversity and be inclusive teachers?

- Q4: Have the students of this degree developed the necessary skills to deal with diversity and be inclusive teachers?

- Q5: Have the students of this degree developed the necessary attitudes for dealing with diversity and being inclusive teachers?

- Q6: Are there differences in the knowledge, skills, and attitudes for inclusion and attention to diversity based on the students' gender, class attendance, the year in which they are enrolled, or their chosen specialization? 


\subsection{Participants}

The sample of the study included students of the degree in primary education from the University of La Laguna (Spain). A sample of 440 students was obtained from the four courses that comprise the degree. In total, there were 293 females and 147 males with an age range between 18 and $44(\bar{x}=21.40 ; \mathrm{SD}=3.73)$. There were students from the first grade $(n=169 ; 38.4 \%)$, second grade $(n=88 ; 20 \%)$, third grade $(n=110 ; 25 \%)$, and fourth grade $(n=73 ; 16.6 \%)$ of the degree. Most of the students reported that they had accessed ULL through the entrance test $(n=365 ; 83 \%)$ and $80 \%$ of the participants reported that they attended class every day.

In response to whether the degree in primary education had been their first option for study at university, $75.6 \%$ responded affirmatively, while $24.4 \%$ of the students answered that they had chosen it as a second or third option.

In addition, when asked whether they had had contact with people with educational needs, $38.6 \%$ responded affirmatively. This contact varied from daily $(13.6 \%)$ to weekly $(11.8 \%)$ to monthly $(13.2 \%)$. These students also reported that this contact had improved their training regarding attention to diversity, improving their practice considerably $(35.6 \%)$, appreciably $(33.9 \%)$, or somewhat $(28.7 \%)$. Only $0.7 \%$ stated that their practice had not been affected by this contact.

\subsection{Instrument}

For data collection, an ad hoc survey was designed on the competencies for being an inclusive teacher and addressing diversity: survey on inclusive knowledge, skills, and attitudes of students in the degree in primary education (COHAAC-INLCU Survey). The survey can be found in Appendix A. The competencies of the inclusive teacher profile proposed in the European project EADSNE [15], which was developed in the instrument designed by Izuzquiza [5], were used as a reference.

The content and structural validity was analyzed using a judge system. Five judges and experts ( 3 men and 2 women) with different professional categories, experts in the subject, and with experience in educational research were selected. Three rounds of evaluations were conducted. In the first round of review, they were asked to assess the survey at a general level. In the following rounds, a more thorough review was performed, for which a survey was developed for them to report on the content, coherence, clarity, and appropriateness of the items.

In order to improve the writing style and to ensure that the questions were written in a clear and accessible language, the latest version of the survey was administered to a pilot sample of characteristics similar to the sample of this study. This pilot sample consisted of 100 students with a mean age of 21.18 years ( $\mathrm{SD}=2.98$ ), of whom $41 \%$ were male and $59 \%$ female. These students belonged to all four years of the degree; $46 \%$ were from the first year, $19 \%$ from the second year, $20 \%$ from the third year, and $15 \%$ from the fourth year. The participants stated that the wording of the items was adequate and that each of the items was clearly understood, deeming it unnecessary to modify any of the items.

The survey consisted of two large sections of questions. The first section included 10 questions related to socio-demographic data (gender, age, class attendance, chosen subject, and interaction with people with specific needs, among others). The second section grouped the four competencies, with their corresponding items referring to knowledge, skills, and attitudes. Thus, the first competence responding to student diversity consisted of 14 items related to understanding diversity as a value; the second competence, attending to all students, consisted of 14 items related to the understanding that all students are different and the necessity to attend to all students. The third competence, with 7 items, referred to teamwork and working in a collaborative manner. Finally, the competence of continuous professional development of teachers was composed of 12 items regarding the ability to improve educational practice based on reflection and continuous training. For each of the items, the response range was a Likert scale from 1 to 7 , where 1 represented "I 
do not agree at all" and 7 represented "I strongly agree". Figure 2 shows the structure of the survey.

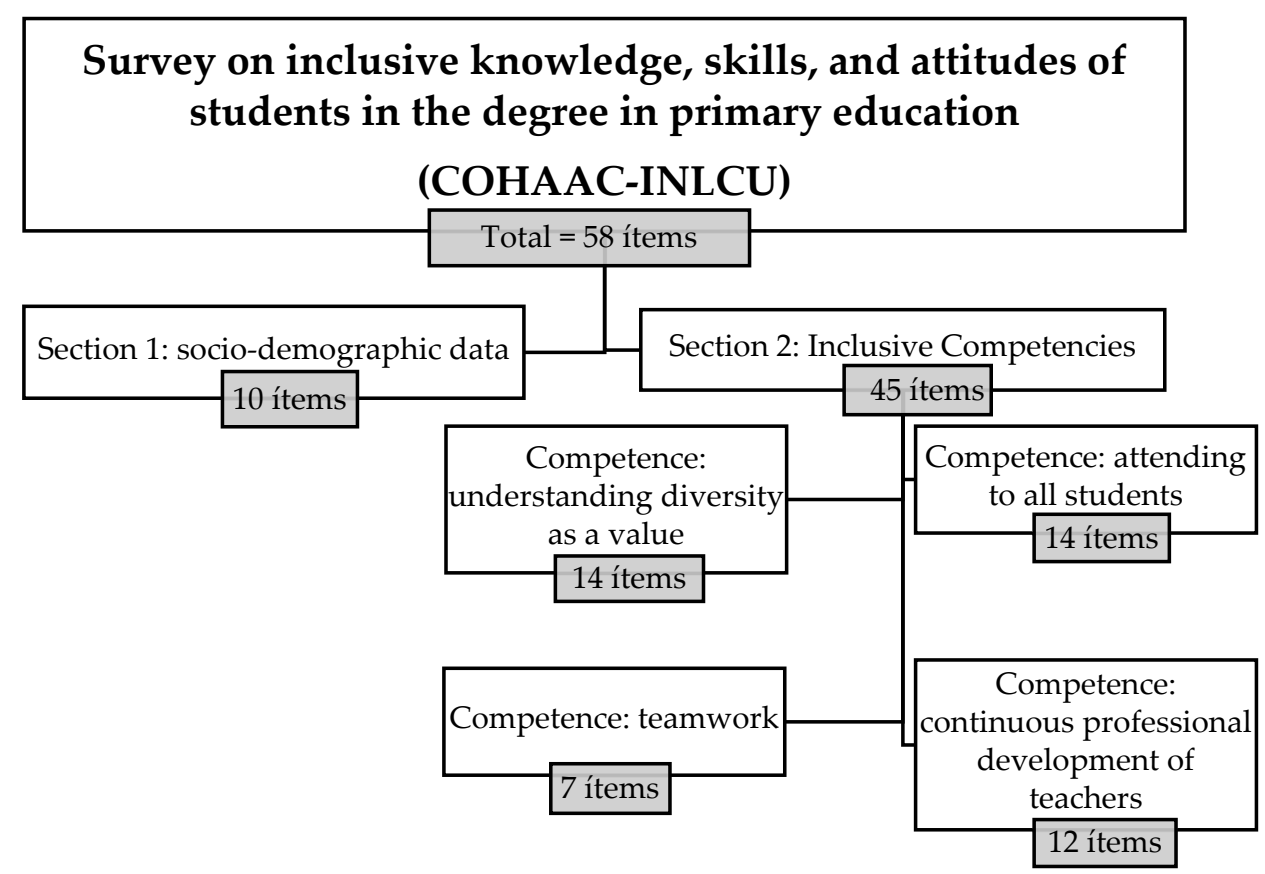

Figure 2. Final structure of the survey on inclusive knowledge, skills, and attitudes of students in the degree in primary education (COHAAC-INLCU).

In order to conduct a more detailed analysis of teachers' knowledge, skills, and attitudes in terms of the four competences of the inclusive teacher profile, an exploratory factor analysis was performed. The KMO test $=0.934$, and Bartlett was significant $\left(x^{2}=11,124.222\right.$, $\mathrm{gl}=1128, p<0.000)$, revealing the correlations between the items to be sufficiently large to perform a principal component analysis (PCA) with orthogonal rotation (varimax). Three factors were found to have eigenvalues above the Kaiser criterion 1 and explained $44.37 \%$ of the variance. Factor I: knowledge about attention to diversity and inclusion, grouped 16 items, Factor II: skills for attending to diversity and favor inclusion, grouped 17 items, and Factor III: attitudes toward attention to diversity and inclusion, grouped 15 items. McDonald's omega $(\omega)$ was used, as it was considered more robust for working with factor loadings [31-33]. The reliability was 0.93 for the total scale, $\omega=0.91$ for Factor I, $\omega=0.92$ for Factor II, and $\omega=0.78$ for Factor III.

\subsection{Procedure}

The academic staff were contacted, and they were given 15-20 min at the end of the class to administer the survey to the students. The survey was administered in printed format during class time. Prior to administering the survey, the purpose of the research was explained to the students and their participation was requested on a voluntary basis. It was also explained that the data were anonymous and that the results of the research would be made available upon request.

\subsection{Data Analysis}

The data were analyzed using SPSS for Windows (version 24). Data screening was performed in order to clean the database. The data obtained were used to check the distribution of the sample. Kurtosis and skewness values $(\neq 0)$ and Kolmogorov-Smirnov (KS) and Shaphiro Wilks (SW) $(p<0.005)$ were calculated. The analyses showed that the data did not follow a normal distribution. Subsequently they were analyzed using 
non-parametric statistics: Mann-Whitney U and Kruskal-Wallis H. Epsilon squared $\left(E_{R}^{2}\right)$ was used to analyze the effect size [34]. This coefficient assumes values located between 0 and 1 , where 0.20 refers to a small effect size, 0.50 to a medium size, and 0.80 to a large effect size [35].

\section{Results}

Two sections are used to present the results. The first section analyzed the results obtained in terms of the competencies explained in the profile of the inclusive teacher [26], and the second section presents the results in terms of the factors that were found: knowledge, skills, and attitudes of the students.

Considering the teacher profile for inclusive education proposed by EADSNE [27] and the four competences it proposes, the results showed the students to have a good command of all. Specifically, they showed a higher level of development in the area acknowledging that being an inclusive teacher requires ongoing professional development $(\mathrm{M}=5.32 ; \mathrm{SD}=0.90)$, followed by understanding the need to respond to diversity $(M=5.20 ; \mathrm{SD}=0.69)$, and to attend to all students $(M=5.03 ; S D=0.85)$. Finally, although they also rated positively with regard to their development of the competence teamwork $(\mathrm{M}=4.79 ; \mathrm{SD}=1.14)$, this was the competence in which their score reflected the least development.

Furthermore, a comparative analysis showed that there were no significant differences based on participants' gender. However, there were significant differences in the four competencies of the inclusive teaching profile attributable to the grades of the students, with fourth-year students self-reporting a higher development of the four competencies. In all cases a small effect size $\left(E_{R}^{2}\right)$ was observed $(<20)$. Table 1 presents the average ranges of all participants according to the course in which they are enrolled. This table shows the scores are of the fourth year students to be higher.

Table 1. Inclusive competencies development by grades $(n=440)$.

\begin{tabular}{|c|c|c|c|c|c|c|c|}
\hline \multirow{2}{*}{ Competencies } & \multirow{2}{*}{$H$} & \multirow{2}{*}{$p$} & \multirow{2}{*}{$E_{R}^{2}$} & \multicolumn{4}{|c|}{ Average Ranges } \\
\hline & & & & 1st & 2nd & 3rd & 4th \\
\hline Responding to the diversity of the student & 24.217 & 0.000 & 0.055 & 190.97 & 229.19 & 221.09 & 277.49 \\
\hline Attention to all students & 32.870 & 0.000 & 0.074 & 191.21 & 229.44 & 211.14 & 291.64 \\
\hline Teamwork & 31.778 & 0.000 & 0.072 & 184.58 & 243.44 & 218.63 & 278.82 \\
\hline Continuous professional development of teachers & 47.403 & 0.000 & 0.107 & 173.85 & 225.60 & 242.72 & 288.88 \\
\hline
\end{tabular}

In order to further analyze the results, post hoc tests were performed to discover between which specific courses the differences occurred. The post hoc tests showed that, with respect to the competence responding to student diversity, the differences appeared between the fourth-year students and the first and third-year students. Students in the final year were found to be more developed. In addition, students in the fourth year were found to have a higher development of the competence, attention to all students, than those in the other years.

The post hoc test results in the competence teamwork showed a higher development among students in the fourth year, who outperformed students in the first and third years. Furthermore, differences were found between first and second year students, with the latter having a higher level of development.

Finally, post hoc tests showed differences in teachers' continuing professional development competencies. In this case, first-year students showed a much lower level of development than the rest of the grades. Significant differences were also found between fourth and second year students, with those in the final year showing the highest level of development. Table 2 shows the differences found between grades. 
Table 2. Differences in inclusive teacher competencies between grades.

\begin{tabular}{|c|c|c|c|c|c|}
\hline Competencies & Pairs & Test Statistic & Deviation of the Test Statistic & $p$ & $p$ Adjusted \\
\hline \multirow{2}{*}{$\begin{array}{l}\text { Responding to the } \\
\text { diversity of students }\end{array}$} & 1st-4th & -86.520 & -4.86 & 0.000 & 0.000 \\
\hline & 3 rd-4th & -56.402 & -2.40 & 0.003 & 0.020 \\
\hline \multirow{3}{*}{ Attention to all students } & 1st-4th & -100.430 & -5.64 & 0.000 & 0.000 \\
\hline & 2 nd-4th & -62.194 & -3.09 & 0.002 & 0.012 \\
\hline & 3rd-4th & -80.496 & -4.19 & 0.000 & 0.000 \\
\hline \multirow{3}{*}{ Teamwork } & 1st-2nd & -58.855 & -3.52 & 0.000 & 0.000 \\
\hline & $1 \mathrm{st}-4 \mathrm{th}$ & -94.239 & -5.29 & 0.000 & 0.000 \\
\hline & 3 rd-4th & -60.195 & -3.13 & 0.002 & 0.010 \\
\hline \multirow{4}{*}{$\begin{array}{l}\text { Continuous professional } \\
\text { development of teachers }\end{array}$} & 1st-2nd & -51.765 & -3.09 & 0.002 & 0.012 \\
\hline & $1 \mathrm{st}-3 \mathrm{rd}$ & -68.872 & -4.42 & 0.000 & 0.000 \\
\hline & 1 st-4th & -115.031 & -6.46 & 0.000 & 0.000 \\
\hline & 2nd-4th & -63.274 & -3.14 & 0.002 & 0.010 \\
\hline
\end{tabular}

As can be seen in Table 3, significant differences appear between the development of competencies and the frequency of contact with people with educational needs. Students who maintained daily contact developed more favorably in all four competencies in comparison with students without contact with people with educational needs.

Table 3. Development of inclusive competencies as a function of contact with people with educational needs $(n=440)$.

\begin{tabular}{|c|c|c|c|c|c|c|c|}
\hline \multirow{2}{*}{ Competencies } & \multirow{2}{*}{$H$} & \multirow{2}{*}{$p$} & \multirow{2}{*}{$E_{R}^{2}$} & \multicolumn{4}{|c|}{ Average Range } \\
\hline & & & & $\mathbf{D}$ & $\mathbf{W}$ & $\mathbf{M}$ & WC \\
\hline Responding to the diversity of students & 20.083 & 0.000 & 0.045 & 285.68 & 231.32 & 212.72 & 205.61 \\
\hline Attention to all students & 11.495 & 0.009 & 0.026 & 264.67 & 235.72 & 227.08 & 206.34 \\
\hline Teamwork & 17.596 & 0.001 & 0.040 & 280.83 & 228.43 & 221.69 & 205.31 \\
\hline Continuous professional development of teachers & 27.050 & 0.000 & 0.061 & 297.18 & 230.09 & 206.53 & 204.61 \\
\hline
\end{tabular}

Note: D: diary, W: weekly, M: monthly, WC: without contact.

The post hoc tests showed that when developing the competencies responding to diversity, students who maintained daily contact with people with educational needs showed greater development, highlighted from students who did not maintain contact or who only maintained contact on a monthly basis. Likewise, differences were found between students who had daily contact and those who did not maintain contact with regard to the competence of attention to diversity and teamwork. Students in contact showed a better development in both competencies.

Finally, differences in the competence, continuing professional development, were analyzed. The results of the post hoc tests revealed a significant difference between the students who had daily contact and the rest of the students, the former evidencing a better development of the competencies (see Table 4).

However, when we inquired about the knowledge (Factor I) that the undergraduate students had about handling diversity, we found that most of the students had sufficient knowledge to promote inclusion and encourage attention to diversity in their classrooms $(\mathrm{M}=4.31 ; \mathrm{SD}=1.10)$. Specifically, $35.2 \%$ of students reported that they had a good (high) development of the knowledge needed to provide personalized learning for students $(\mathrm{M}=4.90$; $\mathrm{SD}=1.40$ ), and $34.8 \%$ that they were able to identify the appropriate learning potential of each student $(\mathrm{M}=4.84 ; \mathrm{SD}=1.37)$, and to contribute to creating schools that stimulate learning and achievement for all students $(\mathrm{M}=4.74 ; \mathrm{SD}=1.55)$. Furthermore, $30 \%$ felt prepared to handle the needs of their students during their learning process $(\mathrm{M}=4.67 ; \mathrm{SD}=1.46)$. 
Table 4. Differences in inclusive teacher competencies among students with different frequencies of contact with people with educational needs.

\begin{tabular}{cccccc}
\hline Competencies & Pairs & Test Statistic & Deviation of the Test Statistic & $p$ & $\begin{array}{c}p \\
\text { Adjusted }\end{array}$ \\
\hline Responding to the & D-WC & 80.069 & 4.41 & 0.000 & 0.000 \\
diversity of students & D-M & 72.959 & 3.11 & 0.002 & 0.011 \\
\hline Attention to all students & D-WC & 58.326 & 3.21 & 0.001 & 0.000 \\
Teamwork & D-WC & 75.524 & 4.16 & 0.000 & 0.000 \\
\hline \multirow{2}{*}{$\begin{array}{c}\text { Continuous professional } \\
\text { development of teachers }\end{array}$} & D-WC & 92.560 & 5.10 & 0.005 & 0.000 \\
& D-W & 67.088 & 2.78 & 0.000 & 0.001 \\
\hline
\end{tabular}

Note: D: diary, W: weekly, M: monthly, WC: without contact.

Almost one-third of the students reported that their level of knowledge was low with respect to the following items: the training received during the degree studies to become teachers for all students regardless of students' abilities, interests, gender, social differences, culture, religion, etc. $(29.1 \% ; \mathrm{M}=3.66$; $\mathrm{SD}=1.73)$; and knowledge of the legal framework supporting inclusive education and attention to diversity $(28.4 \% ; \mathrm{M}=3.86 ; \mathrm{SD}=3.78)$.

The results in skills development showed that students considered themselves to have a good development of the skills needed for catering to diversity and being inclusive teachers ( $M=5.07 ; \mathrm{SD}=0.99)$. Specifically, $71.4 \%$ of the students considered themselves to have a high level of reflective development conducive to the improvement of their practice $(\mathrm{M}=5.91 ; \mathrm{SD}=1.33)$ and to learning from other professionals and improving inclusive practice $(70 \% ; \mathrm{M}=5.91 ; \mathrm{SD}=1.27)$. In addition, more than half of the students reported a high level of mastery of the following skills: self-learning to improve their knowledge and skills about diversity $(61 \% ; M=5.67 ; \mathrm{SD}=1.27)$, reflecting and demonstrating the views of other teachers when appropriate to improve educational response $(54.8 \% ; \mathrm{M}=5.36$; $\mathrm{SD}=1.38$ ), seeking information, resources, and support to respond to students' educational needs $(51.8 \% ; \mathrm{M}=5.42 ; \mathrm{SD}=1.32)$, and critically examining beliefs about students with educational needs $(51.4 \% ; \mathrm{M}=5.28 ; \mathrm{SD}=1.43)$.

In contrast, $15.5 \%$ of students reported low development in working individually with students in heterogeneous and diverse classrooms $(\mathrm{M}=4.69 ; \mathrm{SD}=1.42)$ and in applying conflict resolution strategies with other school professionals to coordinate the response to student diversity $(15.2 \% ; \mathrm{M}=4.31 ; \mathrm{SD}=1.59)$.

The third factor involved connecting items related to attitudes toward attention to diversity and inclusion. The students showed a positive development of these attitudes $(\mathrm{M}=6.00 ; \mathrm{SD}=0.69)$. When attitudes toward diversity were analyzed in detail, it was found that more than $80 \%$ of the students considered that they had good development of the following attitudes: not labeling students so as not to negatively influence their learning $(87.6 \% ; \mathrm{M}=6.45 ; \mathrm{SD}=1.20)$, working for equal rights for all students regardless of their skills and abilities $(86.4 \% ; \mathrm{M}=6.39 ; \mathrm{SD}=1.22)$, the need for continuous training to respond to student diversity $(82 \% ; \mathrm{M}=6.35 ; \mathrm{SD}=1.07)$, and responding to students by avoiding prejudice $(82.7 \% ; \mathrm{M}=6.40 ; \mathrm{SD}=1.07)$.

In analyzing the differences between students' gender and their knowledge (Factor I), skills (Factor II), and attitudes (Factor III), it was found that there were significant differences only in attitudes toward diversity $\left(U=15,853.000 ; p=0.000 ; P S_{e s t}=0.368\right)$, with females showing the most positive attitudes.

Additionally, differences were found with respect to knowledge and skills depending on the course; specifically, fourth-year students showed a higher level of acquisition of knowledge for inclusion (Factor I) $\left(H=28.352 ; p=0.000 ; E_{R}^{2}=0.064\right)$ and a higher development of skills for inclusion (Factor II) $\left(H=38.583 ; p=0.000 ; E_{R}^{2}=0.087\right)$. However, when analyzing the development of attitudes for inclusion (Factor III), it was the third-year students who excelled in this development $\left(H=27.139 ; p=0.000 ; E_{R}^{2}=0.061\right)$. 


\section{Discussion and Conclusions}

The purpose of this research was to analyze whether the students of the degree in primary education had developed the competencies of the inclusive teacher profile proposed by EADSNE [27]. Overall, it was found that students had a good command of the four competencies. However, the results showed a higher development of the competence for continuing professional development. Among the strengths of their training, students highlighted that they were aware of the need for continuous training, as teachers need specific training to deal with diversity. It was also found that women tended to value continuous training most. These results coincide with those obtained by Izuzquina [11]. In addition, the students in this study valued the ability to learn from other professionals in order to be more inclusive and to continuously reflect on their practice.

Similarly, students showed a high level of development of the competence for responding to diversity. Of this competence, the students' understanding of the need to work for equal rights for all regardless of skills and abilities and their awareness of the need to respond to students, avoiding prejudices based on different needs, was notable and especially valued by women. Students also stated that they believed that student diversity enriches classroom practice, an attitude that was particularly emphasized by students who had daily contact with people with educational needs and which coincides with the findings of Izuzquina [11]. Furthermore, consistent with results obtained by these authors, this study also found that students were not sure that their training had prepared them to be teachers of all students, regardless of their abilities, interests, gender, social differences, culture, religion, etc. This result also coincides with other studies [23-26]. Significantly, we found that the students in this study did not consider that attending to diversity in the classroom increased their workload as professionals.

Although the majority of students self-reported that they did not feel that it was im-possible to attend adequately to all students in their classroom, they did state, as we have stated previously, that they had not developed sufficient knowledge and skills to teach and assess students with different needs. This coincides with the finding by Amr et al., [22] in which teachers affirmed that they did not know enough about the problems and needs of these students and that they lacked knowledge to adapt their teaching. Nonetheless, in accordance with results reported in previous studies [11,16,17], students of the degree in primary education considered that they were able to identify the learning potential of each student regardless of their educational needs. Likewise, students, as future teachers, were concerned that students with educational needs would not be accepted by the rest of their classmates, a result that also emerged in other studies [22].

Finally, it was in the teamwork competence that students attained the lowest scores, although the results show that students understood that inclusive education requires teamwork and the ability to reflect and demonstrate the opinions of other teachers when they are appropriate in order to improve the educational response. They also understood the need to collaborate with other teachers, families, and other professionals, all of which help to foster a positive environment and enhance inclusion [35].

In relation to the knowledge, skills, and attitudes toward inclusive education that they have been acquired during their undergraduate training, the development of attitudes by these students is noticeable. As in previous studies, [24,26] women showed a higher development in the attitudes toward inclusion. As has been confirmed, positive attitudes toward inclusion promote better attention to students and constitute a fundamental element for the success of the teaching-learning process $[8,15,16,18,35]$. Likewise, the development of knowledge, skills, and attitudes was greater in the students of the last years. This suggests that the current curriculum is effective in sensitizing students about attention to diversity and educational inclusion, although we cannot forget other factors that may have an influence, such as the students' own maturity.

This does not preclude our indication to the detection of other shortcomings directly related to the training of these students, such as knowledge of teaching and assessment methodologies for attending to diversity, a weakness identified in other studies [25] This 
suggests the need for future modifications to the training plans of the degree. Providing future education professionals with the necessary competencies to continue progressing toward educational and social inclusion cannot continue to be associated with or conditioned by the choice of a given specialization or by disciplinary training in the final years of the training plan. In fact, the results of this study confirmed that it was the students with experience with people with educational needs who had the most firmly established competencies to be inclusive professionals, which coincides with other investigations that affirm that experience and a specific formation improve the attention to this type of student [23-25].

\subsection{Implications for Practice}

Training gaps related to training for educational inclusion and attention to diversity were identified. The students stated that they did not have the adequate knowledge corresponding to the educational profile of inclusive teachers. These limitations or training gaps require a deeper analysis, from research and practice, of what competencies (knowledge, skills, and attitudes) are necessary to respond to diversity. This would favor the training that students receive in the degree.

Another finding was the relationship between students who had experience with people with educational needs and the development of their competencies to be inclusive professionals. It will be interesting to propose a practical approach in the degree, one allowing students to work with people with educational needs and thus develop their knowledge, skills, and attitudes.

\subsection{Limitations}

Limitations were encountered in conducting this research. One of the main limitations was the lack of specific previous studies that would have allowed us to contrast the results obtained with those found in other university contexts. Although there is extensive literature on teachers' attitudes toward inclusion and although the profile of the inclusive teacher was based on a European project [21,27], we are unaware of other research studies analyzing this profile as it was addressed in this paper. This represents a limitation when interpreting and discussing results.

Furthermore, limitations were also found at the methodological level, which must be considered when interpreting the results. The cross-sectional nature of the design in this research and causal interpretations be analyzed with caution. Notwithstanding the potential of the survey, designed to collect reliable and validated information, the lack of a triangulation of this information through direct classroom observations or the use of other more qualitative techniques, such as focus groups, prevents us from affirming unequivocally the development of the competencies developed in the degree. Although we were aware of this limitation, the arduous and complex process involved in collecting information prevented the use of mixed methodologies in the research.

Despite these limitations, the analysis of the competence profile for inclusion in the degree in primary education allows us to propose improvements in the training plan as well as to open up future lines of research.

Author Contributions: Conceptualization, C.N.A.-R., O.M.A.d.l.R. and R.G.-R.; methodology, C.N.A.R., O.M.A.d.1.R. and R.G.-R.; software, C.N.A.-R., O.M.A.d.1.R. and R.G.-R.; validation, C.N.A.-R., O.M.A.d.1.R. and R.G.-R.; formal analysis, C.N.A.-R., O.M.A.d.l.R. and R.G.-R.; investigation, C.N.A.R., O.M.A.d.1.R. and R.G.-R.; resources, C.N.A.-R., O.M.A.d.1.R. and R.G.-R.; data curation, C.N.A.-R., O.M.A.d.l.R. and R.G.-R.; writing-original draft preparation, C.N.A.-R., O.M.A.d.l.R. and R.G.R.; writing-review and editing, C.N.A.-R., O.M.A.d.l.R. and R.G.-R.; visualization, C.N.A.-R., O.M.A.d.1.R. and R.G.-R.; supervision, C.N.A.-R., O.M.A.d.1.R. and R.G.-R.; project administration, C.N.A.-R., O.M.A.d.1.R. and R.G.-R.; funding acquisition, C.N.A.-R., O.M.A.d.l.R. and R.G.-R. All authors have read and agreed to the published version of the manuscript.

Funding: This research was funded by ERASMUS+ PROGRAM (EUROPEAN COMISSION). Grant number: 2019-1-ES01-KA203-065752, Master to Educate in diversity and social inclusion. 
Institutional Review Board Statement: Not applicable.

Informed Consent Statement: Informed consent was obtained from all subjects involved in the study.

Data Availability Statement: Not applicable.

Conflicts of Interest: The authors declare no conflict of interest.

\section{Appendix A}

Survey on Inclusive Knowledge, Skills and Attitudes of Primary Education Students Instructions for completing the survey:

This survey consists of a scale to know the knowledge, skills, and attitudes that the students of the degree in primary education have in relation to inclusion and attention to diversity.

You must read each of the sentences and mark with an X your answer. You can only mark one answer for each of the items. Do not forget to answer ALL the questions and remember that there are no right or wrong answers, answer as honestly as possible all the items. The survey is anonymous, and the data collected will be kept confidential.

Thank you for your collaboration!

\section{Sociodemographic data}

1. Age:

Sex: Male ( ) Female ( )

2. Year in which you have enrolled in the most subjects: 1st ( ) 2nd ( ) 3rd ( ) 4th ( )

3. You entered the Degree in Primary Education through:

( ) University Entrance Exam

() Higher Level Training Cycle

( ) Over 25 years of age

( ) Other qualifications/degrees. Which one?

4. Was the Degree in Primary Education your first choice? YES ( ) NO ( )

5. Do you attend classes every day: YES ( ) NO ( )

6. What is the specialization that you are currently pursuing or are planning to pursue?

( ) Mention in Attention to Diversity

( ) Special Mention in Foreign Language: English

( ) Special Mention in Foreign Language: French

( ) Mention in Music Education

( ) Mention in Physical Education

( ) Minor in Curricular Innovation and Research

7. What do you plan to do when you finish your Degree in Primary Education?

( ) Another university degree. Which one?

( ) A university master's degree. Which one?

( ) A specialization course. Which one?

( ) Looking for a job.

( ) To prepare for the competitive examination to become a teacher.

() Other. Which one?

8. Do you have contact with people with educational needs?

() Yes, daily.

( ) Yes, weekly

( ) Yes, monthly.

( ) I do not have contact with people with educational needs.

9. If you have had contact with people with educational needs, has having had direct experience with people with needs improved your training in relation to attention to diversity???

() It has not contributed anything to my practice.

() It has contributed something to my practice.

( ) It has contributed a lot to my practice. 
( ) It has contributed a lot to my practice.

\section{Scale on inclusive knowledge, skills and attitudes}

Mark with an $\mathrm{X}$ according to your degree of agreement with the following items, considering that 1 is NOT AT ALL AGREE and 7 is TOTALLY AGREE.

\begin{tabular}{|c|c|c|c|c|c|c|c|}
\hline 1. Respond to the diversity of the student & 1 & 2 & 3 & 4 & 5 & 6 & 7 \\
\hline Student diversity enriches classroom practice. & 1 & 2 & 3 & 4 & 5 & 6 & 7 \\
\hline $\begin{array}{c}\text { Students should be given a response, avoiding prejudices based on the different needs they } \\
\text { present. }\end{array}$ & 1 & 2 & 3 & 4 & 5 & 6 & 7 \\
\hline $\begin{array}{l}\text { I am concerned that attending to the diversity of students will increase my workload in the } \\
\text { classroom. }\end{array}$ & 1 & 2 & 3 & 4 & 5 & 6 & 7 \\
\hline I have to work for equal rights for all students, regardless of their skills and abilities. & 1 & 2 & 3 & 4 & 5 & 6 & 7 \\
\hline Labeling students can negatively influence their learning. & 1 & 2 & 3 & 4 & 5 & 6 & 7 \\
\hline Inclusive education is for all students, not just those diagnosed with special needs. & 1 & 2 & 3 & 4 & 5 & 6 & 7 \\
\hline $\begin{array}{l}\text { I have the knowledge to remove barriers that limit the participation of students with needs } \\
\text { in the classroom. }\end{array}$ & 1 & 2 & 3 & 4 & 5 & 6 & 7 \\
\hline $\begin{array}{l}\text { I know that in order to respond to diversity it is essential to consider each student in a } \\
\text { comprehensive manner (personal, academic, social, emotional factors, etc.). }\end{array}$ & 1 & 2 & 3 & 4 & 5 & 6 & 7 \\
\hline I know how to adequately use the terminology and language of inclusion and diversity. & 1 & 2 & 3 & 4 & 5 & 6 & 7 \\
\hline $\begin{array}{l}\text { I know the factors that condition the inclusion process: educational policies, educational } \\
\text { practices, attitudes, etc. }\end{array}$ & 1 & 2 & 3 & 4 & 5 & 6 & 7 \\
\hline I can identify the student's learning style in order to offer the best response. & 1 & 2 & 3 & 4 & 5 & 6 & 7 \\
\hline I can identify the learning pace of students to offer them the best response. & 1 & 2 & 3 & 4 & 5 & 6 & 7 \\
\hline $\begin{array}{c}\text { I am prepared to contribute to create schools that stimulate learning and achievement of all } \\
\text { students. }\end{array}$ & 1 & 2 & 3 & 4 & 5 & 6 & 7 \\
\hline $\begin{array}{l}\text { I believe that the training received during my studies of the Degree in Primary Education } \\
\text { has prepared me to be a teacher of all students, regardless of their abilities, interests, gender, } \\
\text { social differences, culture, religion, etc. }\end{array}$ & 1 & 2 & 3 & 4 & 5 & 6 & 7 \\
\hline 2. Attention to all students & 1 & 2 & 3 & 4 & 5 & 6 & 7 \\
\hline Teacher expectations influence student success. & 1 & 2 & 3 & 4 & 5 & 6 & 7 \\
\hline It is impossible to properly serve all students in the classroom. & 1 & 2 & 3 & 4 & 5 & 6 & 7 \\
\hline $\begin{array}{l}\text { As a future teacher, I am concerned that students with educational needs are not accepted } \\
\text { by the rest of the classmates. }\end{array}$ & 1 & 2 & 3 & 4 & 5 & 6 & 7 \\
\hline $\begin{array}{l}\text { I take into account the social, cultural and ideological background of the students and their } \\
\text { families. }\end{array}$ & 1 & 2 & 3 & 4 & 5 & 6 & 7 \\
\hline I can identify the learning potential of each student, regardless of their educational needs. & 1 & 2 & 3 & 4 & 5 & 6 & 7 \\
\hline $\begin{array}{c}\text { I am able to provide personalized learning that allows each student to improve his/her } \\
\text { competencies. }\end{array}$ & 1 & 2 & 3 & 4 & 5 & 6 & 7 \\
\hline I am prepared to face the needs that students may present in their learning process. & 1 & 2 & 3 & 4 & 5 & 6 & 7 \\
\hline $\begin{array}{l}\text { The studies of the Degree in Primary Education have allowed me to develop knowledge } \\
\text { and skills necessary to teach and evaluate students with different needs. }\end{array}$ & 1 & 2 & 3 & 4 & 5 & 6 & 7 \\
\hline I am able to work individually with students in heterogeneous and diverse classrooms. & 1 & 2 & 3 & 4 & 5 & 6 & 7 \\
\hline $\begin{array}{l}\text { I am able to apply in the classroom strategies that promote the participation of all students } \\
\text { (teamwork, cooperative work, peer tutoring, etc.). }\end{array}$ & 1 & 2 & 3 & 4 & 5 & 6 & 7 \\
\hline $\begin{array}{c}\text { I have the necessary ability to seek information, resources and support to respond to the } \\
\text { educational needs of students. }\end{array}$ & 1 & 2 & 3 & 4 & 5 & 6 & 7 \\
\hline I am able to adjust and adapt activities to offer the necessary support to all students. & 1 & 2 & 3 & 4 & 5 & 6 & 7 \\
\hline
\end{tabular}




\begin{tabular}{|c|c|c|c|c|c|c|c|}
\hline $\begin{array}{l}\text { I know how to apply different techniques and strategies to evaluate the performance of } \\
\text { students with or without special needs. }\end{array}$ & 1 & 2 & 3 & 4 & 5 & 6 & 7 \\
\hline $\begin{array}{l}\text { I am able to apply a variety of teaching methodologies to support the learning of students } \\
\text { with and without difficulties. }\end{array}$ & 1 & 2 & 3 & 4 & 5 & 6 & 7 \\
\hline $\begin{array}{l}\text { I am able to implement different modalities of teamwork among students (planning, } \\
\text { developing and evaluating them). }\end{array}$ & 1 & 2 & 3 & 4 & 5 & 6 & 7 \\
\hline 3. Teamwork & 1 & 2 & 3 & 4 & 5 & 6 & 7 \\
\hline Inclusive education requires teamwork. & 1 & 2 & 3 & 4 & 5 & 6 & 7 \\
\hline $\begin{array}{l}\text { I have learned to use strategies to communicate and coordinate with the family and other } \\
\text { external professionals (associations, health personnel, etc.) to provide a better response to } \\
\text { all students. }\end{array}$ & 1 & 2 & 3 & 4 & 5 & 6 & 7 \\
\hline I know teamwork techniques to coordinate with other teachers of the center. & 1 & 2 & 3 & 4 & 5 & 6 & 7 \\
\hline $\begin{array}{l}\text { I know the terminology and concepts related to the attention to diversity and educational } \\
\text { inclusion necessary to work with other special needs support professionals. }\end{array}$ & 1 & 2 & 3 & 4 & 5 & 6 & 7 \\
\hline $\begin{array}{l}\text { I know how to apply conflict resolution strategies with other professionals of the center to } \\
\text { coordinate the response to student diversity. }\end{array}$ & 1 & 2 & 3 & 4 & 5 & 6 & 7 \\
\hline $\begin{array}{l}\text { I can work collaboratively to respond to the needs of students with different agents } \\
\text { (families, other professionals, specific associations, health personnel, special needs support } \\
\text { teachers, etc.). }\end{array}$ & 1 & 2 & 3 & 4 & 5 & 6 & 7 \\
\hline $\begin{array}{l}\text { I have the ability to reflect and put into practice the opinions of other teachers when they } \\
\text { are appropriate to improve the educational response. }\end{array}$ & 1 & 2 & 3 & 4 & 5 & 6 & 7 \\
\hline 4. Permanent professional development of the teaching staff & 1 & 2 & 3 & 4 & 5 & 6 & 7 \\
\hline $\begin{array}{l}\text { I am aware that in order to respond to the diversity of students, continuous training is } \\
\text { necessary. }\end{array}$ & 1 & 2 & 3 & 4 & 5 & 6 & 7 \\
\hline I have learned to critically examine my beliefs about students with educational needs. & 1 & 2 & 3 & 4 & 5 & 6 & 7 \\
\hline A teacher must be knowledgeable in everything related to inclusive education. & 1 & 2 & 3 & 4 & 5 & 6 & 7 \\
\hline A teacher needs to have specific training to provide an adequate response to diversity. & 1 & 2 & 3 & 4 & 5 & 6 & 7 \\
\hline I know the legal framework that supports inclusive education and attention to diversity. & 1 & 2 & 3 & 4 & 5 & 6 & 7 \\
\hline I have basic knowledge to address the difficulties of students in the classroom. & 1 & 2 & 3 & 4 & 5 & 6 & 7 \\
\hline I master strategies to evaluate the impact of my work on the students' performance. & 1 & 2 & 3 & 4 & 5 & 6 & 7 \\
\hline I am able to learn from other professionals to improve my inclusive practice. & 1 & 2 & 3 & 4 & 5 & 6 & 7 \\
\hline I am able to learn on my own to improve my knowledge and skills about diversity. & 1 & 2 & 3 & 4 & 5 & 6 & 7 \\
\hline I am sufficiently prepared to adapt my teaching strategies to student diversity. & 1 & 2 & 3 & 4 & 5 & 6 & 7 \\
\hline $\begin{array}{l}\text { I know how to use different information and communication technologies (ICT) to provide } \\
\text { a better response to all students, with or without special needs. }\end{array}$ & 1 & 2 & 3 & 4 & 5 & 6 & 7 \\
\hline I continually reflect to improve my practice. & 1 & 2 & 3 & 4 & 5 & 6 & 7 \\
\hline
\end{tabular}

\section{References}

1. Valcarce, M. De la escuela integradora a la escuela inclusiva. Innovación Educ. 2011, 21, 119-131.

2. Díaz, N. Escuela inclusiva: Construcción democrática de sociedad en Chile. Rev. Iberoam. Educ. 2011, 55, 1-8. [CrossRef]

3. Fernández, J.M. Competencias docentes y educación inclusiva. Rev. Electrónica Investig. Educ. 2013, 15, 82-99.

4. Arnaiz, P. Hacia una educación eficaz para todos: La educación inclusiva. Educar 2000 2002, 5, 15-19.

5. Casanova, M.A. Supervisión y educación inclusiva. Avances en la Supervisión Educativa: Revista de la Asociación de Inspectores de Educación De España 2011, 14, 1-14. (In Spanish)

6. Organización de las Naciones Unidas para la Educación, la Ciencia y la Cultura UNESCO. Directrices Sobre Políticas de Inclusión en la Educación; UNESCO: Paris, France, 2009.

7. Alegre, O.M. Diversidad Humana y Educación; Aljibe: Málaga, Spain, 2000.

8. Alegre, O.M. Educar en la Diversidad: Bases Conceptuales; Grupo Editorial Universitario: Madrid, Spain, 2002. 
9. Alegre, O.M.; Villar, L.M. Inclusión e Interculturalidad. Un estudio en el marco de la enseñanza universitaria. Rev. Nac. E Int. Educ. Inclusiva 2015, 8, 12-29.

10. Vélaz, C.; Vaillant, D. Aprendizaje Y Desarrollo Profesional Docente; Organización de Estados Iberoamericanos para la Educación, la Ciencia y la Cultura (OEI); Fundación Santillana: Madrid, Spain, 2009. (In Spanish)

11. Izuzquiza, D.; Echeita, G.; Simón, C. La percepción de estudiantes egresados de magisterio en la Universidad Autónoma de Madrid sobre su competencia profesional para ser "profesorado inclusivo": Un estudio preliminar. Tend. Pedagógicas 2015, 26, 197-216.

12. Barceló, M.; López, E.; Camilli, C. Análisis de las competencias genéricas del docente de educación primaria. Estudio de caso. In Las Competencias Básicas. Competencias Profesionales Del Docente; Nieto, E., Callejas, A., Jerez, O., Eds.; Universidad de Castilla-La Mancha: Ciudad Real, España, 2012; pp. 21-31.

13. Hollins, E. Teacher preparation for quality teaching. J. Teach. Educ. 2011, 62, 395-407. [CrossRef]

14. Pesquero, E.; Sánchez, M.; González, M.; Martín, R.; Guardia, S.; Cervelló, J.; Fernández, P.; Martínez, M.; Varela, P. Las competencias profesionales de los maestros de Primaria. Rev. Española Pedagog. 2008, 241, 447-466.

15. Granada, M.; Pomés, M.; Sanhueza, S. Actitud de los profesores hacia la inclusión educativa. Pap. Trabajo. Cent. Estud. Interdiscip. Etnolingüística Antropol. Socio-Cult. 2013, 25, 51-59.

16. Idol, L. Toward Inclusion of Special Education Students in General Education. A Program Evaluation of Eight Schools. Remedial Espec. Educ. 2006, 27, 77-94. [CrossRef]

17. Sales, A.; Moliner, O.; Sanchiz, M.L. Actitudes hacia la atención a la diversidad en la formación inicial del profesorado. Rev. Electrónica Interuniv. Form. Del Profr. 2001, 4, 1-7.

18. Sánchez, A.; Díaz, C.; Sanhueza, S.; Friz, M. Percepciones y actitudes de los estudiantes de pedagogía hacia la inclusión educativa. Estud. Pedagógicos 2008, 34, 169-178. [CrossRef]

19. Amatori, G.; Mesquita, H.; Rosário, M. Special Education for inclusion in Europe: Critical issues and comparative perspectives for teachers' education between Italy and Portugal Education. Sci. Soc. 2020, 1, 78-89. [CrossRef]

20. Alegre, O.M.; Villar, L.M. Attitudes of Children with Hearing Loss towards Public Inclusive Education. Educ. Sci. 2019, 9, 244. [CrossRef]

21. European Agency for Development in Special Needs Education (EADSNE). Formación del Profesorado Para la Educación Inclusiva en Europa. Retos y Oportunidades; Dirección General de Educación y Cultura de la Comisión Europea: Brussels, Belgium, 2011. (In Spanish)

22. Amr, M.; Al-Natour, M.; Al-Abdallat, B.; Alkhamra, H. Primary school teachers' knowledge, attitudes and views on barriers to inclusion in Jordan. Int. J. Spec. Educ. 2013, 31, 67-77.

23. Bawa Kuyini, A.; Desai, I.; Sharma, U. Teachers' self-efficacy beliefs, attitudes and concerns about implementing inclusive education in Ghana. Int. J. Incl. Educ. 2018, 24, 1509-1526. [CrossRef]

24. Pegalajar, M.C.; Colmenero, M.J. Actitudes y formación docente hacia la inclusión en Educación Secundaria Obligatoria. Rev. Electrónica Investig. Educ. 2017, 19, 84-97. [CrossRef]

25. González-Gil, F.; Martín-Pastor, E.; Flores, N.; Jenaro, C.; Poy, R.; Gómez-Vela, M. Teaching, Learning and inclusive education: The challenge of teachers' training for inclusión. Procedia-Soc. Behav. Sci. 2013, 93, 783-788. [CrossRef]

26. Avramidis, E.; Bayliss, P.; Burden, R. Student teachers' attitudes towards the inclusion of children with special educational needs in the ordinary school. Teach. Teach. Educ. 2000, 16, 277-293. [CrossRef]

27. European Agency for Development in Special Needs Education (EADSNE). Teacher Education for Inclusion. Profile of Inclusive Teachers; Dirección General de Educación y Cultura de la Comisión Europea: Brussels, Belgium, 2012. (In Spanish)

28. Ato-García, M.; Vallejo, G. Diseños de Investigación en Psicología; Pirámide: Madrid, España, 2015.

29. Hernández, R.; Fernández-Collado, C.; Batista, P. Metodología de la Investigación, 6st ed.; McGraw-Hill: Mexico D.F., Mexico, 2014.

30. Navas, M.J. Métodos, Diseños Y Técnicas de Investigación Psicológica; UNED: Madrid, España, 2001.

31. Ventura-León, J.; Caycho-Rodríguez, T. El coeficiente Omega: Un método alternativo para la estimación de la confiabilidad. Rev. Latinoam. Cienc. Soc. Niñez Juv. 2017, 15, 625-627.

32. Viladrich, C.; Angulo-Brunet, A.; Doval, E. Un viaje alrededor de alfa y omega para estimar la fiabilidad de consistencia interna. An. Psicol. 2017, 33, 755-782. [CrossRef]

33. Peters, G.Y. The alpha and the omega of scale reliability and validity. Eur. Health Psychol. 2014, 16, 56-69.

34. Tomczak, M.; Tomczak, E. The need to report effect size estimates revisited. An overview of some recommended measures of effect size. Trends Sport Sci. 2014, 1, 19-25.

35. Ballhysa, N.; Flagler, M. A Teachers' Perspective of Inclusive Education for Students with Special Needs in a Model Demonstration Project. Acad. Int. Sci. J. 2011, 3, 121-133. 